\title{
STUDI KEMITRAAN DESA ADAT DENGAN PELAKU USAHA WISATA UNTUK PENGEMBANGAN EKOWISATA LOVINA DI KABUPATEN BULELENG
}

\author{
Made Arie Wahyuni
}

Masuk: 01042017 / Diterima: 01052017 / Dipublikasi: 30062017

(c) 2017 Fakultas Hukum dan IImu Sosial UNDIKSHA dan IGI

\begin{abstract}
The study was conducted in Lovina area of Buleleng Regency with the objectives of: (1) Identifying the tourism potential for the development of Lovina ecotourism, (2) Describing the partnership form of traditional village and (3) Analyzing contribution from partnership form in Lovina ecotourism development. The design of the study using descriptive design. Determination of sample using purposive sampling and purposive sampling technique. Data were collected by observation techniques, interviews, documentation, and document recording. The analytical method used is qualitative analysis. The results showed: (1) tourism potential includes 4 aspects that is tourist attractions, tourist accommodation, access roads and institutions;(2) There are four forms of partnership: Contract of Manage, Lease contract, Building Use Rights (BUR) and, the concession contract; (3) The form of partnership contributes positively to the development, namely partnerships, BUR, and concessions. Forms of partnership contracts are contributing to the development of ecotourism. Location and land ownership factors greatly affect the interaction with all aspects of tourism. Especially the low income revenue compared with another actors.
\end{abstract}

Key words: Partnership, Indigenous Village, Tourism Business Actors, Ecotourism

Abstrak Penelitian dilaksanakan di Kawasan Lovina Kabupaten Buleleng dengan tujuan: (1) Mengidentifikasi potensi wisata yang dimitrakan untuk pengembangan ekowisata Lovina, (2) Mendeskripsikan bentuk kemitraan yang dilakukan desa adat dan (3) Menganalisis kontribusi dari bentuk kemitraan dalam pengembangan ekowisata Lovina. Rancangan penelitian menggunakan rancangan deskriptif. Penentuan sampel menggunakan teknik purposive area sampling dan purposive sampling. Data dikumpulkan dengan teknik observasi, wawancara, dokumentasi, dan pencatatan. Metode analisis yang adalah kualitatif. Hasil penelitian menunjukkan: (1) Potensi wisata mencakup 4 aspek yaitu atraksi wisata, akomodasi wisata, akses jalan dan kelembagaan; (2) Terdapat 4 bentuk kemitraan yaitu Kontrak Kelola, Kontrak Sewa, Hak Guna Bangunan (HGB) dan Kontrak Konsesi; (3) Bentuk kemitraan berkontribusi positif yaitu bentuk kemitraan kelola, HGB, dan konsesi. Bentuk kemitraan kontrak sewa kontribusinya sedang terhadap pengembangan ekowisata. Faktor lokasi dan kepemilikan lahan sangat mempengaruhi interaksi dengan seluruh aspek kepariwisataan, khususnya penerimaan pendapatan yang rendah dibandingkan pelaku wisata lain.

Kata kunci: Kemitraan, Desa Adat, Pelaku Usaha Wisata, Ekowisata

\section{Pendahuluan}

Ekowisata

(ecotourism)

Made Arie Wahyuni

Jurusan Akuntansi, FE UNDIKSHA

Singaraja

wahyuni arie@yahoo.com merupakan hal yang menciptakan dan memuaskan suatu keinginan akan alam, mengeksploitasi potensi wisata untuk konservasi dan pembangunan serta mencegah dampak negatifnya terhadap ekologi, kebudayaan dan 
keindahan (Western, 1995:3). Dengan ekowisata diharapkan dapat menjamin keberlangsungan hidup pariwisata tanpa harus mengorbankan lingkungan.

Dari prinsip pembelajaran tentang alam dan manfaatnya terhadap masyarakat, maka Bali memiliki potensi besar dalam pengembangan ekowisata karena Bali termasuk Kabupaten Buleleng, khususnya objek wisata lovina yang memiliki sejumlah sumber daya alam dan potensi sosial budaya berupa adat-istiadat masyarakat yang mampu menopang pembangunan pariwisata.Hal yang paling mendasar dalam pengelolaan tersebut yaitu untuk memasarkan potensi yang dimiliki yaitu dengan melakukan kerjasama/ bermitra dengan pelaku wisata.

Hal ini merupakan salah satu strategi dalam mengembangkan objek wisata. Kemitraan antara desa adat dengan pelaku usaha wisata merupakan salah satu strategi untuk meningkatkan keuntungan masyarakat lokal baik secara ekonomi, sosial, budaya dan menjaga kelestarian lingkungan.

Kemitraan dalam lingkungan masyarakat yang merupakan sesuatu hal yang tidak asing untuk diterapkan, karena bangsa ini sudah mengenal kemitraan sejak berabad-abad lamanya meskipun dalam skala yang sederhana, seperti gotong royong, sambat sinambat, partisipasi, mitra cai, mitra masyarakat desa hutan, mitra lingkungan dan sebagainya.

Dalam manajemen modern, baik dalam pengembangan sumberdaya manusia maupun pengembangan kelembagaan/ usaha, kemitraan merupakan salah satu strategi yang biasa ditempuh untuk mendukung keberhasilan implementasi manajamen modern (Kamil, 2006: 1). Kemitraan tidak sekadar diterjemahkan sebagai sebuah kerjasama, akan tetapi kemitraan memiliki bentuk, memiliki nilai strategis dalam mewujudkan keberhasilan suatu lembaga dalam menerapkan manajemen modern termasuk dalam pengembangan ekowisata.

Hal ini menarik untuk dikaji karena kawasan ekowisata selain merupakan sumber pendapatan masyarakat juga berfungsi untuk konservasi keanekaraganam hayati dan kelestarian budaya masyarakat lokal. Dengan demikian dipandang perlu diteliti secara mendalam agar masyarakat lokal memiliki pemahaman tentang bentuk kemitraan, yaitu bahwa pentingnya pemasaran produk wisata pada objek wisata dengan menjalin kerjasama dengan pelaku usaha wisata sehingga masyarakat akan memperoleh manfaat dari segi pemberdayaan masyarakat, ekonomi dan ekologis (melestarikan lingkungan kawasan objek wisata). Berdasarkan hal tersebut, adapun tujuan penelitian ini yaitu 1) mengidentifikasi potensi wisata yang dimitrakan untuk pengembangan ekowisata Lovina; 2) mendeskripsikan bentuk kemitraan yang dilakukan desa adat dalam pengembangan ekowisata Lovina; 3) menganalisis kontribusi dari bentuk kemitraan dalam pengembangan ekowisata Lovina. Hal ini perlu mendapatkan perhatian yang proporsional dari berbagai kalangan, khususnya bagi pemerintah daerah sehingga mampu merumuskan strategi kebijakan terkait dengan kemitraan dalam pengembangan ekowisata. 


\section{Metode}

Penelitian ini dilakukan di Daya Tarik Wisata Lovina Kabupaten Buleleng. Rancangan penelitian menggunakan rancangan deskriptif. Penentuan sampel menggunakan teknik purposive area sampling dan purposive sampling. Data dikumpulkan dengan teknik observasi, wawancara, dokumentasi, dan pencatatan dokumen. Metode analisis yang digunakan yaitu analisis kualitatif.

\section{Hasil dan Pembahasan}

\section{Potensi wisata yang dimitrakan untuk pengembangan ekowisata Lovina}

Potensi wisata mencakup 4 aspek yang wajib dikelola. Pengelolaan tersebut akan lebih mudah jika dimitrakan dengan pihak lain. Lovina merupakan salah satu objek wisata pesisir di Kabupaten Buleleng. Dikatakan objek wisata pesisir karena daya tarik wisata dominan dari potensi pesisir dan kelautan yaitu atraksi lumba-lumba dan pemandangan pantainya. Daya tarik pendukung kawasan wisata Lovina yakni pantai dengan panorama yang indah dan intensitas matahari yang cukup menjadikan daya tarik tersendiri bagi wisatawan untuk berdatangan ke daerah wisata Lovina. Dinas Kebudayaan Dan Pariwisata Kabupaten Buleleng menggelar even bertaraf internasional bernama Festival Lovina, biasanya beragam budaya akan dipamerkan pada saat hari pembukaan, hal ini merupakan bentuk usaha pemerintah yang didukung sejumlah komponen masyarakat dan industri pariwisata guna mempromosikan dan membangkitkan kawasan Lovina kedepannya. Fasilitas untuk akomodasi seperti hotel atau penginapan, tersebar di pinggiran jalan dari luar gerbang pantai Lovina tersebar sampai disekitar jalan menuju pantai Lovina. Hotel atau penginapan yang ditawarkan juga dalam bentuk berbagai macam dengan fasilitasnya yang memadai. potensi wisata ini menjadi aspek yang dimitrakan antara Desa adat maupun Desa Dinas Kalibukbuk dengan pihak seperti Pemerintah Daerah Kabupaten Buleleng, dan Pelaku Usaha Wisata. Berdasarkan hasil wawancara dengan Kepala Desa Kalibukbuk, pelaku usaha wisata yang membuka usaha di Lovina harus menandatangani surat perjanjian kesepahaman tentang perekrutan tenaga kerja $75 \%$ dari warga lokal. Catatan yang tidak tertulis juga disampaikan seperti bersedia membantu untuk kegiatan upacara adat maupun keagamaan yang dilaksanakan di Desa Kalibukbuk. Dalam pelestarian lingkungan, seperti desa adat lain di Bali, Desa Adat Kalibukbuk juga menerapkan awig-awig. Seperti melakukan kegiatan pembersihan tiap sebulan sekali disekitar pantai, disamping dilakukan oleh petugas kebersihan yang melakukan setiap harinya. Sedangkan untuk pengolahan limbah, dilakukan hanya sekadar membakar sampah. Karena masingmasing pelaku usaha wisata sudah melaksanakan pengolahan limbahnya sendiri. Aspek kelembagaan yang dimitrakan adalah membentuk badan pengelola daya tarik wisata lovina. Desa adat bekerjasama dengan pemerintah dengan membentuk badan pengelola yang mengatur kegiatan kepariwisataan di Lovina. 


\section{Bentuk kemitraan yang dilakukan desa adat dalam pengembangan ekowisata Lovina}

Penyelenggaraan kegiatan

bersama dengan lembaga mitra merancang program bersama. Pada pelaksanannya bentuk kerjasama yang dilakukan yaitu sebuah lembaga melaksanakan seluruh kegiatan pada tahapan pengelolaan program. Desa adat Kalibukbuk bersama dengan Pemerintah Daerah Kabupaten Buleleng membentuk sebuah lembaga untuk melaksanakan pengelolaan obyek wisata Lovina. Lembaga yang dimaksud adalah Badan Pengelola Obyek Daya Tarik Wisata Lovina. Selanjutnya untuk menjalankan setiap program dan pengelolaan operasional dilapangan dibentuklah Manajemen Operasional Daya Tarik Wisata Lovina untuk menjalankan program kegiatan yang telah disepakati bersama antara pemerintah daerah beserta desa adat.

Tenaga kerja yang digunakan yaitu karyawan yang bekerja di obyek wisata Lovina sudah disepakati hanya merekrut dari masyarakat Desa Kalibukbuk. Kenyataanya semua yang menduduki kepengurusan manajemen operasional dan staff adalah orangorang dari dalam Desa Kalibukbuk, dari tingkat manajer sampai pada petugas kebersihan.

Sesuai dengan keputusan bersama terkait dengan kerjasama pemanfaatan lahan Tirta Wisata yang berlokasi di Desa Keplaksari perlu dilakukan secara profesional, baik secara administrasi, pemeliharaan, pemasaran serta pengembangannya dengan tujuan mampu meningkatkan ekonomi masyarakat sekitar Tirta Wisata (Kurniawan, 2013)
Hal yang melatarbelakangi atau mendasari terbentuknya kemitraan atau kerjasama seperti tersebut dimuka, kemudian dapat diidentifikasi bentuk kemitraan yang ada di obyek wisata Lovina yaitu sebagai berikut.

\section{Kontrak Kelola}

Kontrak kelola merupakan bentuk kerjasama dimana mitra swasta diberi tanggung jawab untuk mengelola prasarana/ sarana milik pemerintah atau desa adat. Aspek yang dikontrakkan adalah jabatan dalam suatu organisasi/ manajemen saja. Hal yang dimaksud yaitu Desa Adat Kalibukbuk bersama dengan Pemda Kabupaten Buleleng membentuk manajemen operasional untuk melakukan pengelolaan obyek wisata. Akan tetapi yang membedakannya dengan teori yaitu pihak manajemen berasal dari warga masyarakat adat itu sendiri. Setiap program kegiatan dari Badan Pengelola yang dicanangkan, Manajemen Operasional DTW Lovina memiliki hak dan kewajiaban dalam pelaksanaanya. Walaupun demikian dalam pelaksanaannya kegiatan kepariwisataan yang dilakukan tetap berada dalam budaya adat istiadat sebagai pedomannya. Untuk memperlancar pengelolaan kegiatan kepariwisataan dengan ikatan budaya desa adat maka akan lebih efektif menggunakan warga setempat yaitu warga Desa Adat Kalibukbuk. Hal ini sudah tentu warga yang memenuhi kualifikasi untuk dapat bekerja sebagai manajer ataupun staf yang memiliki peranan yang paling penting. Disamping itu alasan menggunakan tenaga dari warga setempat yaitu menumbuhkan rasa memiliki dan 
kepedulian terhadap obyek wisata Lovina dan pemberdayaan bagi masyarakat lokal. Seperti hasil penilitian dari Rustiono, 2014 lembaga yang mengatur pengelolaan Desa Wisata Pendidikan Pertanian diselenggarakan oleh masyarakat bekerjasama dengan pemerintah daerah dan pihak swasta.

\section{KontrakSewa}

Kontrak sewa merupakan bentuk kerjasama dimana pelaku usaha wisata menyewa suatu fasilitas infrastruktur (kios/toko) tertentu dalam jangka waktu tertentu untuk kemudian dioperasikan dan dipelihara. Pelaku usaha wisata menyediakan modal kerja untuk pengoperasian dan pemeliharaan yang dimaksud, termasuk penggantian bagian-bagian tertentu. Pada obyek wisata Lovina, bentuk kemitraan ini dilakukan oleh pelaku usaha wisata dengan badan pengelola obyek wisata (pemerintah, desa adat dan manajemen operasional). Karena lahan yang ditempati oleh pelaku usaha wisata milik pemerintah daerah, dengan demikian pelaku usaha wisata menyewa lahan dan minta izin usaha kepada pihak manajemen operasional daya tarik wisata Lovina.

\section{Hak Guna Bangunan (HGB)}

HGB merupakan bentuk kerjasama antara badan pengelola (pemerintah daerah dan desa adat) dengan pelaku usaha wisata. Lahan yang ditempati oleh pelaku usaha wisata adalah milik desa adat, bangunan kios/toko dibangun oleh pemerintah, dan pelaku usaha wisata membeli kios/toko saja dan lahan tersebut tetap milik desa adat. Pelaku usaha wisata dapat menyewakan atau menjual kiosnya, tetapi tidak boleh menjual lahannya karena status kepemilikan lahan adalah milik desa adat.

\section{Kontrak Konsesi}

Kontrak konsesi merupakan bentuk kerjasama dimana pelaku usaha wisata diberi tanggung jawab menyediakan jasa pengelolaan atas sebagian atau seluruh potensi wisata termasuk pengoperasian dan pemeliharaan fasilitas. Hal ini karena pelaku usaha wisata membangun usahanya di lahan miliknya. Dengan demikian pihak pengelola memberikan tanggung jawab kepada pelaku usaha wisata dalam pembangunan dan pemeliharaan potensi wisata. Kerjasama ini terjalin dengan kesepakatan untuk membagi keuntungan atau dengan membayar retribusi kepada pihak pegelola (pemerintah, desa adat dan manajemen operasional).

Dari semua bentuk kerjasama yang ada di DTW Lovina, terdapat kesamaan pada masing-masing bentuk yaitu tetap dari aspek ekologis yaitu tetap menjaga kelestarian lumba-lumba dab budaya berupa melakukan kegiatan upacara agama sehingga kelestarian budaya tetap terjaga, secara ekonomi yaitu disamping membayar retribusi harian, pihak pengelola dapat membuka peluang usaha sehingga akan berdampak pada peningkatan pendapatan masyarakat pelaku usaha wisata, dan terkait dengan pemberdayaan masyarakat pihak mananajemen tetap mengutamakan masyarakat lokal yang diterima sebagai karyawan dan pelaku 
usaha wisata di DTW Lovina. Berdasarkan teori bentuk kemitraan yang digunakan dalam penelitian ini pada prinsipnya sudah sesuai walaupun terdapat perbedaan dalam hal substansi dan redaksinya. Misalnya pada bentuk kemitraan yang dilakukan antara pihak pengelola DTW Lovina dengan pelaku usaha wisata bedasarkan pada program kegiatan dan tenaga yang digunakan menghasilkan bentuk konsesi. Sedangkan bentuk kemitraan yang berdasarkan pada status kepemilikan lahan menghasilkan bentuk kemitraan kontrak sewa karena lahan milik pemerintah, bentuk kemitraan kontrak kelola karena lahan milik pribadi, dan yang paling menarik dan berbeda dengan teori yaitu bentuk kemitraan Hak Guna Bangunan (HGB) karena lahan yang ditempati adalah milik Desa Adat Kalibukbuk.

\section{Kontribusi Kemitraan dalam Pengembangan Ekowisata Lovina Kabupaten Buleleng}

Berdasarkan pada bentuk kemitraan yang telah dijelaskan sebelumnya, selanjutnya akan dianalisis mengenai kontribusinya dalam pengembangan ekowisata. Masing-masing bentuk kemitraan akan memberikan gambaran baik perbedaan ataupun persamaannya pada tiap aspek ekowisata seperti kontribusinya terhadap aspek ekologis, ekonomis dan pemberdayaan masyarakat di obyek wisata Lovina. Dengan menggunakan pedoman kuesioner kepada pelaku usaha wisata dan karyawan di DTW Lovina, diperoleh hasil kontribusi masing-masing bentuk kemitraan pada setiap aspek pengembangan ekowisata. Tiap aspek ekowisata diukur dengan memberikan harkat pada masing-masing indikator. Adapun klasifikasi tingkat kontribusi bentuk kemitraan dalam pengembangan ekowisata sebagai berikut.

- 15 - 19,30 (kontribusi rendah)

- 19,40 - 23,70 (kontribusi sedang)

- 23,80 - 28 (kontribusi tinggi)

Pada aspek ekologis, terdapat klasifikasi tingkat kontribusi masingmasing bentuk kemitraan berkontribusi tinggi diantaranya yaitu kontrak kelola memberikan kontribusi tinggi sebesar 26,95, kontrak sewa memberikan kontribusi tinggi sebesar 25,55, Hak Guna Bangunan (HGB) memberikan kontribusi tinggi sebesar 26,80 , kontrak konsesi memberikan kontribusi tinggi sebesar 26,70. Bentuk kemitraan kontrak kelola memiliki skor yang paling tinggi. Hal ini karena pihak yang bermitra merupakan pihak manajemen yang melakukan pengelolaan kawasan wisata Lovina. Rasa memiliki dan rasa kepedulian terhadap kelestarian Lumba-lumba dan Pura Segara Lovina, juga bentuk kemitraan ini merupakan kerjasama pengelola dengan pihak manajemen dimana karyawan/ staff yang menempati struktur organisasi badan operasional DTW Lovina adalah warga Desa Adat Kalibukbuk. Rasa kepemilikan yang besar maka akan berpengaruh pada pengelolaan obyek wisata berdasarkan budaya masyarakat setempatSedangkan bentuk kemitraan kontrak sewa memiliki skor yang paling rendah, hal ini disebabkan karena pihak yang bermitra yaitu pelaku usaha pariwisata memiliki lokasi di lahan parkir yaitu bagian utara dari kawasan 
wisata Lovina. Pada aspek ekonomis, bentuk kemitraan kontrak kelola memberikan kontribusi sedang sebesar 22,04, kontrak sewa memberikan kontribusi rendah sebesar 17,80, Hak Guna Bangunan (HGB) memberikan kontribusi tinggi sebesar 24,10, kontrak konsesi memberikan kontribusi sedang sebesar 23,30. Berdasarkan data tersebut, terdapat perbedaan kontribusi pada masing-masing bentuk kemitraan dalam pengembangan ekowisata. Bentuk kemitraan Hak Guna Bangunan (HGB) berkontribusi tinggi pada aspek ekomomi. Hal ini karena pihak yang melakukan kerjasama yaitu pelaku usaha wisata dengan pihak pengelola, dimana usaha yang dikelola oleh pelaku usaha wisata dibangun diatas tanah milik desa adat sehingga tidak perlu membeli lahan. Bangunan kios/toko dibangun oleh pihak pengelola sehingga biaya yang dikeluarkan bisa lebih hemat jika membangun sendiri. Pelaku usaha wisata hanya perlu membeli kios/toko retribusinya saja. Jika pelaku wisata berhenti berdagang dapat menyewakan kios/ tokonya atau bahkan menjual dengan harga yang stabil.

Sedangkan bentuk kemitraan kontrak sewa memiliki kontribusi yang paling rendah dalam aspek ekonomis. $\mathrm{Hal}$ ini pihak yang bekerjasama dengan pihak pengelola yaitu pelaku usaha wisata yang sebagai pedagang makanan dan minuman yang berlokasi di pelataran lahan parkir DTW Lovina. Pengaruhnya adalah selain lahan yang ditempati adalah milik pemerintah daerah sehingga harus menyewa sekaligus membayar retribusi juga berpengaruh terhadap interaksi yang kurang dengan wisatawan. Wisatawan akan langsung ke lokasi daya tarik utama wisata yaitu Pura Lovina. Wisatwan turun dari kendaraannya di depan pintu masuk pengecekan tiket dan bukan di tempat parkir. Walaupun ada, tidak akan langsung belanja. Dengan demikian akan berpengaruh pada penapatan pelaku usaha wisata ini yang akan langsung terkait pada pengembangan ekowisata dimana harus menguntungkan bagi masyarakat lokal. Bentuk kemitraan kontrak kelola dan dan konsesi berkontribusi sedang terhadap aspek ekonomis ekowisata. Akan tetapi bentuk kemitraan konsesi memiliki skor yang lebih tinggi karena pelaku usaha wisata membangun usahanya selain di tanah miliknya sendiri juga berlokasi di pinggir jalan utama. Peluang untuk mendapatkan wisatwan untuk berbelanja akan lebih mudah. Sedangkan kontrak kelola yaitu pihak manajemen yang lebih mengandalkan gaji dari pendapatan obyek wisata Lovina.

Pada aspek pemberdayaan masyarakat, bentuk kemitraan berkontribusi kontrak kelola memberikan kontribusi tinggi sebesar 27,17, kontrak sewa memberikan kontribusi sedang sebesar 23,35, Hak Guna Bangunan (HGB) memberikan kontribusi tinggi sebesar 25,95, kontrak konsesi memberikan kontribusi tinggi sebesar 25,10. Terdapat tiga bentuk kemitraan yang berkontribusi tinggi dalam pengembangan ekowisata pada aspek pemberdayaan masyarakat. Bentuk kemitraan kontrak kelola memiliki persentase yang tinggi terhadap aspek pemberdayaan masyarakat. Pihak yang menjalin kemitraan adalah pihak pengelola dan pihak manajemen dimana orang-orang 
yang menduduki badan organisasi manajemen operasional DTW Lovina adalah semua dari warga Desa Adat Kalibukbuk. Setiap kegiatan yang akan dilaksanakan akan melibatkan seluruh karyawan manajemen dan pelaku usaha wisata. Begitu jua dengan bentuk kerjasama HGB dan Konsesi dimana pihak yang menjalin kerjasama yaitu pelaku wisata yang sebagian besar berasal dari Desa pakraman Kalibukbuk yang ikut berpartisipasi pada setiap kegiatan pariwisata yang dilakukan, seperti penyuluhan, rapatrapat dan pengawasan obyek wisata Lovina. Sedangkan bentuk kemitraan kontrak sewa berkontribusi sedang dalam pemberdayaan masyarakat. Hal ini karena lokasi pelaku usaha wisata berada dibagian utara kawasan wisata, pengawasan terhadap situs obyek wisata akan tidak efektif, selain itu dalam kegiatan rapat-rapat/ pengambilan keputusan, promosi wisata, penyuluhan tentang kepariwisataan tidak begitu terlibat. Disebabkan karena produk yang dijual hanya bersifat kebutuhan akan primer yaitu makanan dan minuman dimana kebutuhan akan barang-barang seperti ini kecil pengaruhnya di dalam pengembangan ekowisata. Wisatawan yang datang akan lebih tertarik terhadap barang seni atau cendera mata (souvenir) pada obyek wisata.

\section{Penutup}

\section{Simpulan}

Potensi wisata yang $\begin{array}{r}\text { dimitrakan } \\ \text { untuk pengembangan } \\ \text { Lovina }\end{array}$
ekowisata

Potensi wisata mencakup 4 aspek yang wajib dikelola. Pengelolaan tersebut akan lebih mudah jika dimitrakan dengan pihak lain. Adapun aspek yang dimitrakan yaitu atraksi wisata berupa atraksi lumba-lumba dan kegiatan budaya, akomodasi wisata berupa hotel dan restauran, akses berupa jalan dan rambu-rambunya dan kelembagaan berupa badan pengelola.

\section{Bentuk kemitraan yang dilakukan desa adat dalam pengembangan ekowisata Lovina}

Dari empat bentuk kemitraan yang ada di Daya Tarik Wisata Lovina yang dilatarbelakangi oleh status kepemilikan lahan dan program kegiatan yang dimitrakan termasuk didalamnya tenaga yang digunakan dalam proses kemitraan yaitu Kontrak Kelola merupakan bentuk kerjasama dimana mitra swasta diberi tanggung jawab untuk mengelola prasarana/ sarana milik pemerintah atau desa adat.

Aspek yang dikontrakkan adalah jabatan dalam suatu organisasi/ manajemen saja, Kontrak Sewa terjadi karena lahan yang ditempati oleh pelaku usaha wisata milik pemerintah daerah, maka pelaku usaha wisata menyewa lahan dan minta izin usaha kepada pihak manajemen operasional DTW Lovina, Hak Guna Bangunan (HGB) terjadi karena lahan yang ditempati oleh pelaku usaha wisata adalah milik desa adat, bangunan kios/ toko dibangun oleh pemerintah, dan pelaku usaha wisata membeli/ menyewa kios/toko saja dan lahan tersebut tetap milik desa adat, Kontrak Konsesi terjadi karena pelaku usaha wisata memiliki lahan sendiri, maka dapat membuka usaha sesuai dengan kemampuannya. 


\section{Kontribusi dari bentuk kemitraan dalam pengembangan ekowisata Lovina}

Bentuk kemitraan berkontribusi positif dalam pengembangan ekowisata Lovina. Terdapat tiga bentuk kemitraan yang berkontribusi tinggi terhadap pengembangan ekowisata yaitu bentuk kemitraan kelola, HGB, dan konsesi. Bentuk kemitraan kontrak sewa kontribusinya sedang terhadap pengembangan ekowisata. Faktor lokasi dan kepemilikan lahan sangat mempengaruhi interaksi dengan seluruh aspek kepariwisataan. Khusunya tentang penerimaan pendapatan yang rendah dibandingkan dengan pelaku usaha yang berlokasi di dekat situs obyek wisata.

\section{Rekomendasi}

Desa Kalibukbuk memiliki potensi untuk pengembangan daerah pariwisata yang berbasis ekowisata dengan kawasan pantai, atraksi lumbalumba dan situs Pura Segara Lovina serta kegiatan upacara agama yang sekaligus sebagai atraksi wisata berupa budaya lokal.

Selain itu Daya Tarik Wisata Lovina merupakan salah satu sumber pendapatan daerah yang memberi kontribusi yang cukup besar, maka untuk masa-masa yang akan datang perlu diadakan usaha peningkatan pembinaan dan pengembangan ekowisata sebagai industri yang dapat memberikan peluang kerja khususnya bagi masyarakat lokal. Pada intinya pariwisata yang berbasis ekowisata menyediakan keaslian alam dan budaya. Maka untuk itu diperlukan suatu pembinaan diantaranya adalah sebagai berikut.
- Meningkatkan keterampilan masyarakat lokal agar dapat melihat peluang dalam bisnis pariwisata. Seperti peningkatan keterampilan membuat barang-barang kerajinan yang dijadikan cendera mata (souvenir) yang dapat dipasarkan di objek wisata Lovina.

- Perlunya membuat sebuah kebijakan berupa sistem untuk mengatur pemerataan pendapatan bagi pelaku usaha wisata khususnya bagi para pedagang cendera mata (souvenir) dalam penerimaan wisatawan terutama wisatawan mancanegara yang berkunjung untuk berbelanja.

- Perlu kajian lebih lanjut tentang kemitraan dalam pengembangan ekowisata tidak hanya pada pihak pengelola dengan pelaku usaha wisata, tetapi juga mengkaji kemitraan antar pelaku usaha wisata.

\section{Ucapan Terimakasih}

Terimakasih pada Universitas Pendidikan Ganesha dan Lembaga Penelitian Undiksha khususnya dalam memberikan kesempatan, izin dan kontribusi berupa dana penelitian dengan nomor surat perjanjian penugasan penelitian: 101/UN48.15/LT/2016 sehingga penelitian dapat berjalan dan selesai tepat waktu.

\section{Daftar Pustaka}

Baiquni, M. 2010. Pariwisata Berkelanjutan dalam Pusaran Krisis Global. Denpasar: Udayana University Press. 
Rustiono, Dedy., Trimurti., Suparwi. 2014 Modal Desa Wisata Pendidikan Pertanian Berbasis Kewirausahaan Sosial dan Kemitraan (Studi Pengembangan Pariwisata Di Kabupaten Wonogiri Jawa Tengah. Jurnal Agonomika, Vol.09. No. 02. februari -juli 2014. Hal 191-212.

Efendi, Sofian dan Singarimbun, Masri. 1987. Metode Penelitian Survai. Yogyakarta: LP3ES

Kamil, Mustofa. 2006. Strategi Kemitraan Dalam Membangun PNF Melalui Pemberdayaan Masyarakat (Model, Keunggulan dan Kelemahan). http://file.upi.edu/Direktori/SPS/ PRODI.PENDIDIKAN LUAR S EKOLAH/196111091987031MUSTOFA KAMIL/Bhaan kulia h/KEMITR 1.PDF. Diakses tanggal 23 April 2016.

Kurniawan,F., Soesilo Zauhar, Hermawan. 2013. Kemitraan Pengelolaan Sektor (Studi Pada Tirta Wisata Kabupaten Jombang). Jurnal Administrasi Publik (JAP), Vol, No. 1. Hal 47 55.

Pendit. 2002. Ilmu Pariwisata Sebuah Pengantar Perdana. Jakarta : Pradnya Paramitha.

Western, David. 1995. Ekoturisme: Petunjuk Untuk Perencanaan \& Pengelolaan. Jakarta: The Ecotourism Society North Benington, Vermont.

http://www.bulelengkab.go.id/index.php/ pariwisata/19/Wisata-Alam Diakses tanggal 15 April 2015 